\title{
Paleoclimate and Glaciological Reconstruction in Central Asia Through the Collection and Analysis of Ice Cores and Instrumental Data from the Tien Shan
}

\author{
FINAL REPORT \\ 30 May, 2001 \\ DOE Contract Number: FG07-00ID13906 \\ Budget Period: 03/27/2000 to 03/26/2001
}

Vladimir Aizen, Donald Bren School of Environmental Science and Management University of California at Santa Barbara

Karl Kreutz, Stable Isotope Laboratory, Institute for Quaternary and Climate Studies University of Maine

Cameron Wake, Climate Change Research Center, Institute for the Study of Earth, Oceans and Space, University of New Hampshire, Durham, NH 03824

Contact: Tel: 603-862-2329; e-mail: cameron.wake@unh.edu 


\section{OVERVIEW}

While the majority of ice core investigations have been undertaken in the polar regions, a few ice cores recovered from carefully selected high altitude/mid-to-low latitude glaciers have also provided valuable records of climate variability in these regions (Mayewski et al., 1984; Thompson et al., 1989; 1995; 1997; 2000; Aizen et al., 1996, 1997; Wagenbach, 1989; Wake and Mayewski, 1996; Wake et al., 1998; Kreutz and Sholkovitz, 2000). A regional array of high resolution, multi-parameter ice core records developed from temperate and tropical regions of the globe can be used to document regional climate and environmental change in the latitudes which are home to the vast majority of the Earth's human population. In addition, these records can be directly compared with ice core records available from the polar regions and can therefore expand our understanding of inter-hemispheric dynamics of past climate changes.

The main objectives of our paleoclimate research in the Tien Shan mountains of middle Asia combine the development of detailed paleoenvironmental records via the physical and chemical analysis of ice cores with the analysis of modern meteorological and hydrological data. The first step in this research, work that was funded jointly by DOE (this grant) and the National Science Foundation - Paleoclimate Program, was the collection of ice cores from the accumulation zone of the Inylchek Glacier and the collection of meteorological data from a variety of stations throughout the Tien Shan. The research effort described in this report was part of a collaborative effort with the United States Geological Survey's (USGS) Global Environmental Research Program which began studying radionuclide deposition in mid-latitude glaciers in 1995.

During July and August of 2000, an international team of scientists traveled to the Inylchek Glacier in the central Tien Shan (Figure 1) to recover two ice cores and perform a variety of other experiments to assist with the eventual interpretation of the ice core record. Meteorological and hydrological data for the region was also gathered with the assistance of colleagues from Kyrgyzstan.

This collaborative research effort involved scientists from the University of California at Santa Barbara (Vladimir Aizen and Elena Aizen), University of New Hampshire (Cameron Wake), University of Maine (Karl Kreutz), the US Geological Survey (DeWayne Cecil and Jaromy Green), Paul Sherrer Technological Institute (Hans-Arno Synal), Tomsk State University (Stanislav Nikitin), and Kyrgyz-Slavic State University (Artem Atamanov). 


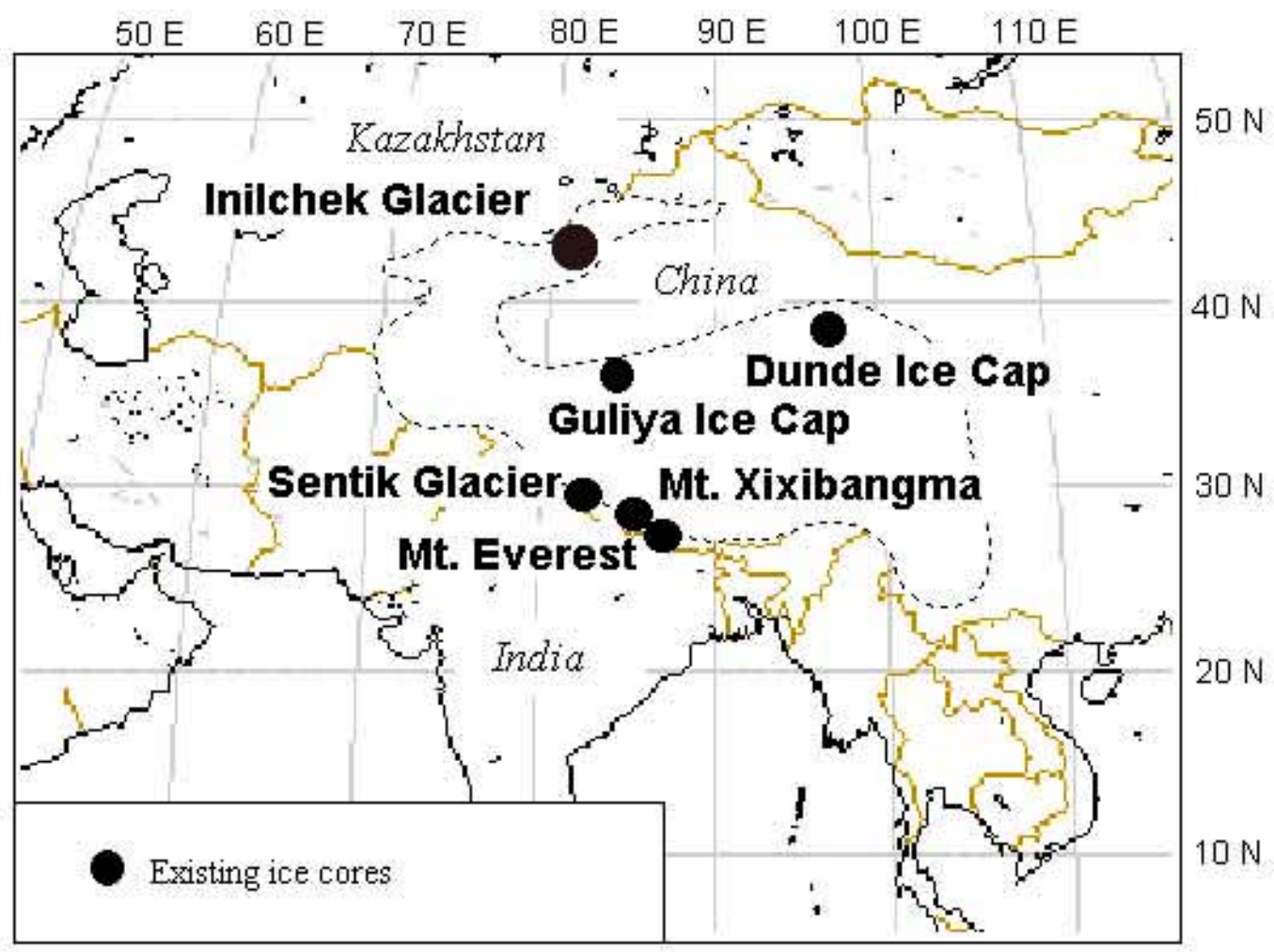

-....... $3000 \mathrm{~m}$ topographic line (outline of the central Asian mountain system)

Figure. 1. Location of the Inylchek Glacier ice core site in the Tien Shan and its relation to other sites in central Asia where ice cores have already been recovered.

\section{RESULTS}

\section{Ice Core Drilling}

During July/August 2000 a major research expedition to the Inylchek Glacier, including 14 scientific and support personnel, was funded jointly by NSF and DOE. The primary goal of the expedition was to recover two deep ice cores for high-resolution paleoclimatic reconstructions. Using the UNH ECLIPSE solar-powered electromechanical auger (Blake et al., 1998), two $165 \mathrm{~m}$ cores $(8.2 \mathrm{~cm}$ diameter) were recovered at 5100 and 5120 meters above sea level in the accumulation zone of the Inylchek Glacier, Central Tien Shan Mountains, Kyrgyzstan (Figure 1). Once drilled, the cores were immediately placed in polyethylene sleeves which were stapled shut. The length, diameter, and weight was measured in order to calculate core density changes with depth; the firn-ice transition (i.e., density greater than $0.8 \mathrm{~g} \mathrm{~cm}^{-3}$ ) occurs at approximately $31 \mathrm{~m}$ below the surface (Figure 2). The cores were then placed in insulated shipping containers that were stored in snow caves two meters below the snow surface in order to keep the cores frozen. All of the cores were transported frozen from the drill site to the freezers at UNH where they are currently stored, awaiting processing and chemical analysis. 


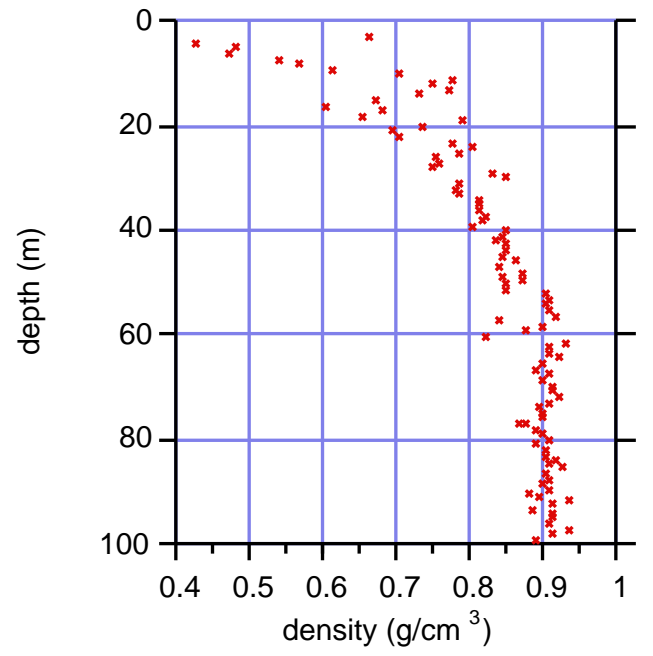

Fig. 2. Density of ice core 1 with depth.
In addition to the ice core drilling, we performed several other important experiments designed to improve our ability to interpret the ice core derived paleoclimatic record we propose to develop. These efforts and the results are summarized below:

\section{Borehole Temperature Measurements}

Borehole ice temperatures at the $5100 \mathrm{~m}$ drilling site (Borehole 1) were taken during four days after the first ice core (167 $\mathrm{m}$ deep) had been extracted. A thermocouple cable with eight stainless steel sensors $(4.8 \mathrm{~mm}$ diameter $/ 125 \mathrm{~mm}$ length) was lowered into the hole and temperatures measured at $1 \mathrm{~m}, 5 \mathrm{~m}, 10$ $\mathrm{m}, 20 \mathrm{~m}, 30 \mathrm{~m}, 50 \mathrm{~m}, 100 \mathrm{~m}$ and $160 \mathrm{~m}$

depth over a three day period (Figure 3). The Grant Instruments 1200 series data logger recorded temperatures every hour. Accuracy of the measurements is better than $0.4^{\circ} \mathrm{C}$ at the range -40 to $+20^{\circ} \mathrm{C}$. The borehole is located between the cold infiltrationrecrystallization and recrystallization zones where snowmelt is negligible. In fact, snowmelt only occurs during a short period of the summer (about 5-10 days) at this elevation. The borehole temperature profile shows a steady negative values from top to the bottom of borehole with minimum $-12{ }^{\circ} \mathrm{C}$ between $10 \mathrm{~m}$ and $50 \mathrm{~m}$. This temperature is similar to the mean annual air temperature for this elevation (as calculated using the Tien Shan station data using temperature with a gradient of $-0.53^{\circ} \mathrm{C}$ per $100 \mathrm{~m}$ ). At greater depths, the temperatures were constant, and the $100 \mathrm{~m}$ and $160 \mathrm{~m}$ temperature was $-11.2^{\circ} \mathrm{C}$, indicating that the glacier at this elevation is frozen to it's bed.

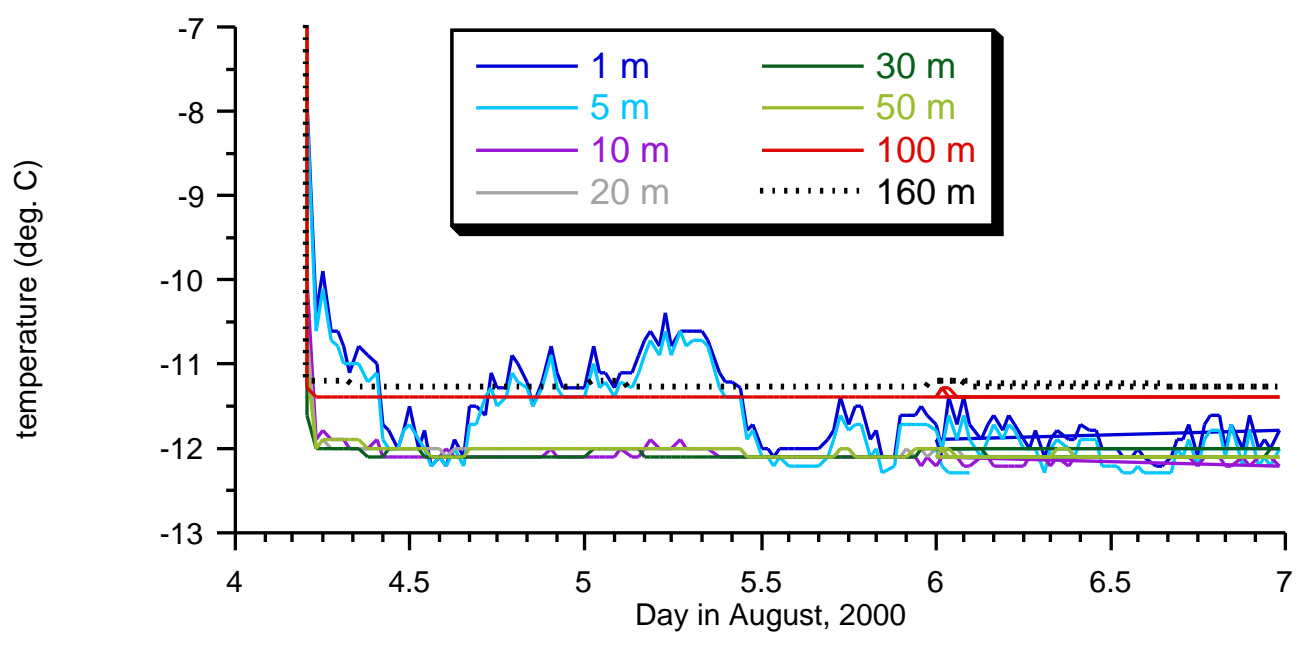

Fig. 3. Borehole temperatures measured over 3 days in August for a variety of depths. 


\section{Ice Thickness Measurements}

Detailed radio-echo sounding measurements were completed at over 150 sites on the glacier in order to determine ice thickness and basin morphology. These measurements were accomplished using a light-weight ice-penetrating radar system ( $30^{\circ}$ direction of aerials, $700 \mathrm{MHz}$ frequency, $10 \mathrm{Watt}$ impulse, 50 NSC duration of impulse, -130 Decibel sensitivity of receiving signal, $1-2 \%$ error of measurement). Measured ice thickness range from 109 to $302 \mathrm{~m}$, with depths at the Borehole 1 and Borehole 2 being 285-300 m and 250-260 m, respectively. Ice thickness at the two core sites were also verified using a separate mono-pulse radio echo sounding system. The results indicate that the glacier bedrock does not have any major depressions, faults, or bends in an explicit form. Internally, the glacier has several intermediate horizons which were apparent in the radio echo sounding reflections that could be associated with the presence of fine-grained sediment of eolian genesis. Water in a liquid form inside the glacier body is not apparent in any of the radio echo sounding data. This conclusion is supported by the absence of any liquid water in the boreholes during the ice core drilling efforts and borehole temperature measurements. Most of the radio-echo thickness measurements were surveyed using a GPS (Figure 4) so that a 3D digital model of the glacier can be developed as a component of our paleoclimatic research.

\section{Snow Sample Collection from Fresh Snowfall Events and Snowpits}

Snow samples were collected for chemical and isotopic analysis from four snowpits and seven fresh snowfall events over a range of elevations (4200-5250 m) in order to investigate the spatial and short term temporal variability in snow chemistry. The major ion concentrations in the fresh snow samples show much larger variability between events compared to changes in concentration with elevation (Figure 5). The isotopic composition of these samples are still being analyzed due to unforeseen delays in equipment delivery. However, data from fresh snow and snowpit samples collected during previous expedition to the Inylchek Glacier (1992, 1998, and 1999) over a wide range of elevations (4100 to $6100 \mathrm{~m}$ ) display insignificant spatial variability at any given elevation (Figure 6). Major ion analyses on the samples collected from the $4 \mathrm{~m}$ snowpits reveals similar concentrations and variability at all four sites (Figure 7). These results indicate that the majority of the variability in the major ion and isotopic content of precipitation in this region is due to changes in air mass characteristics over time and that the elevation of deposition plays no significant role. This is significant as it shows that there will be little, if any, influence on the glaciochemical record of snow that fell at a slightly higher elevation in the accumulation zone and transported with glacier flow down to the drill site 


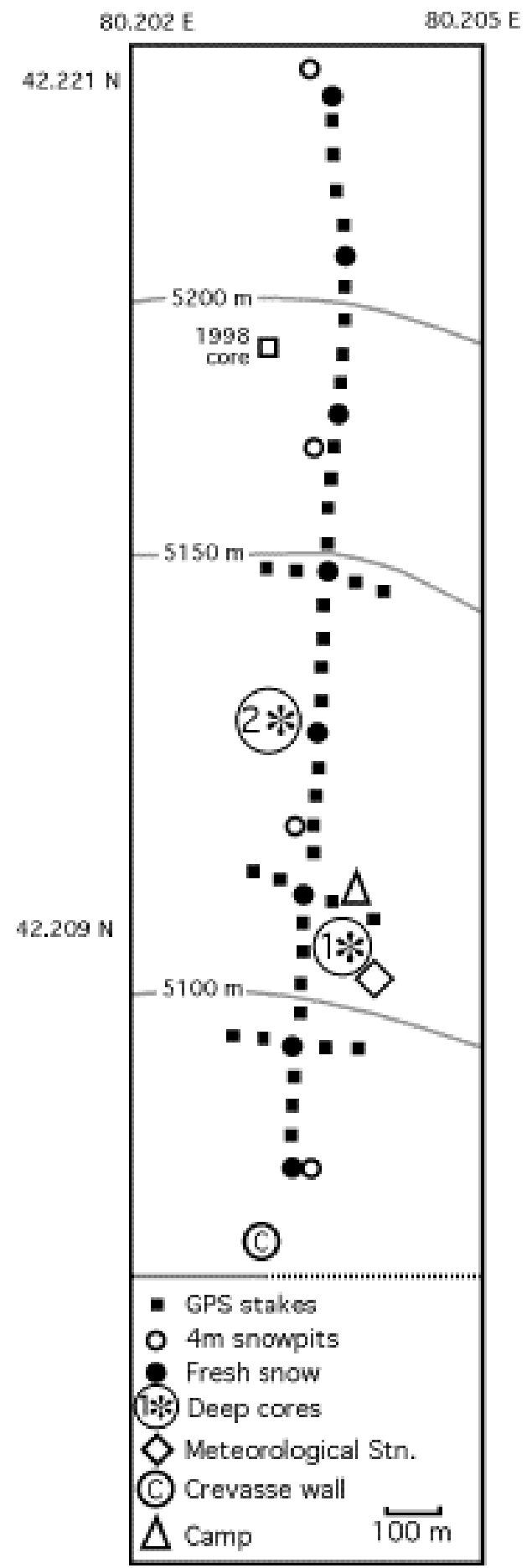

Fig. 4. Map of the accumulation zone of the Upper Inylchek Glacier with location of research activities. 

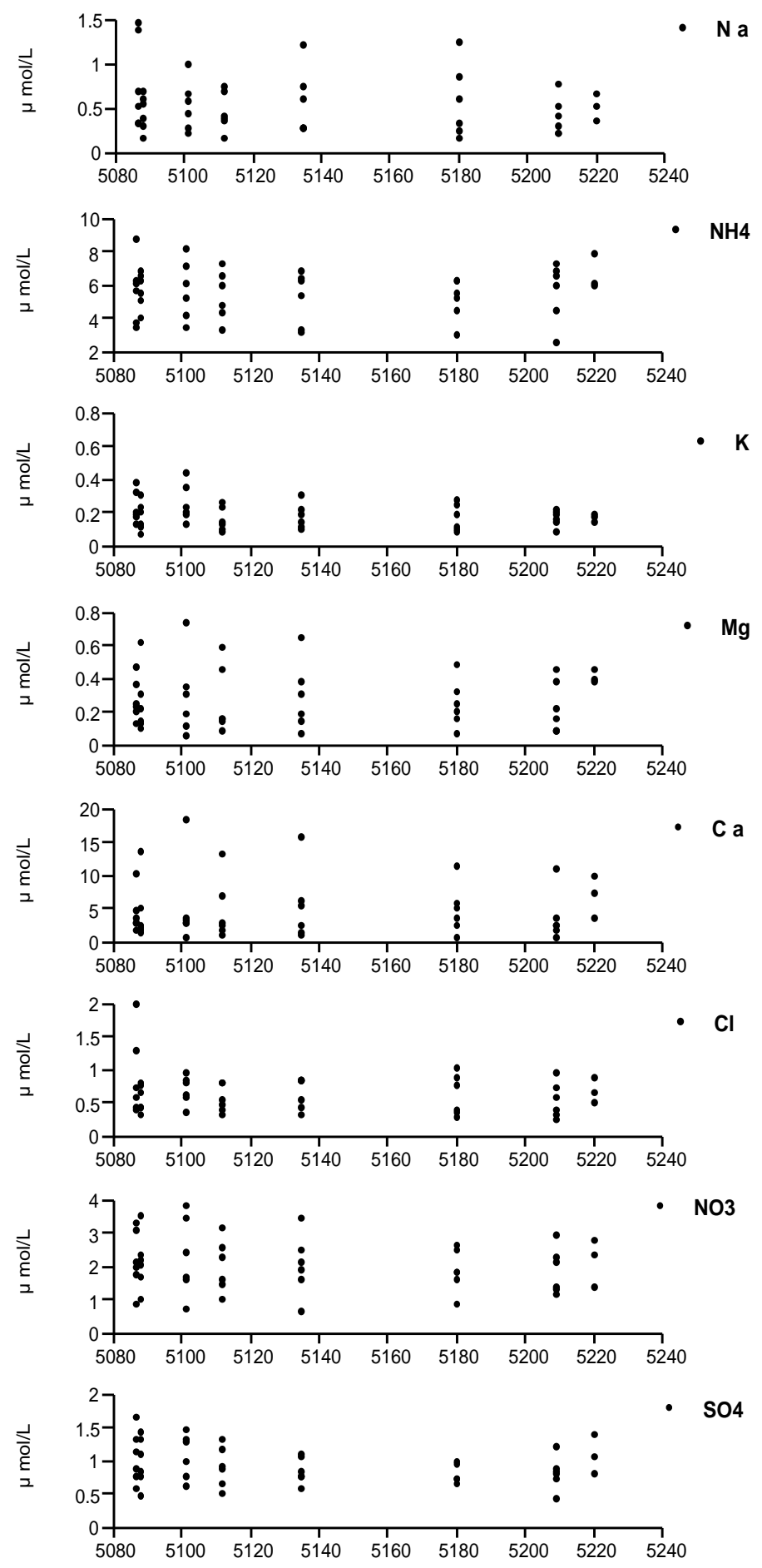

Fig. 5. Major ion concentration in fresh snow samples collected from six different events over a range of elevations (5080 $\mathrm{m}$ to $5240 \mathrm{~m}$ ). Note that the variability at any given elevation is greater than the variation between elevations. 


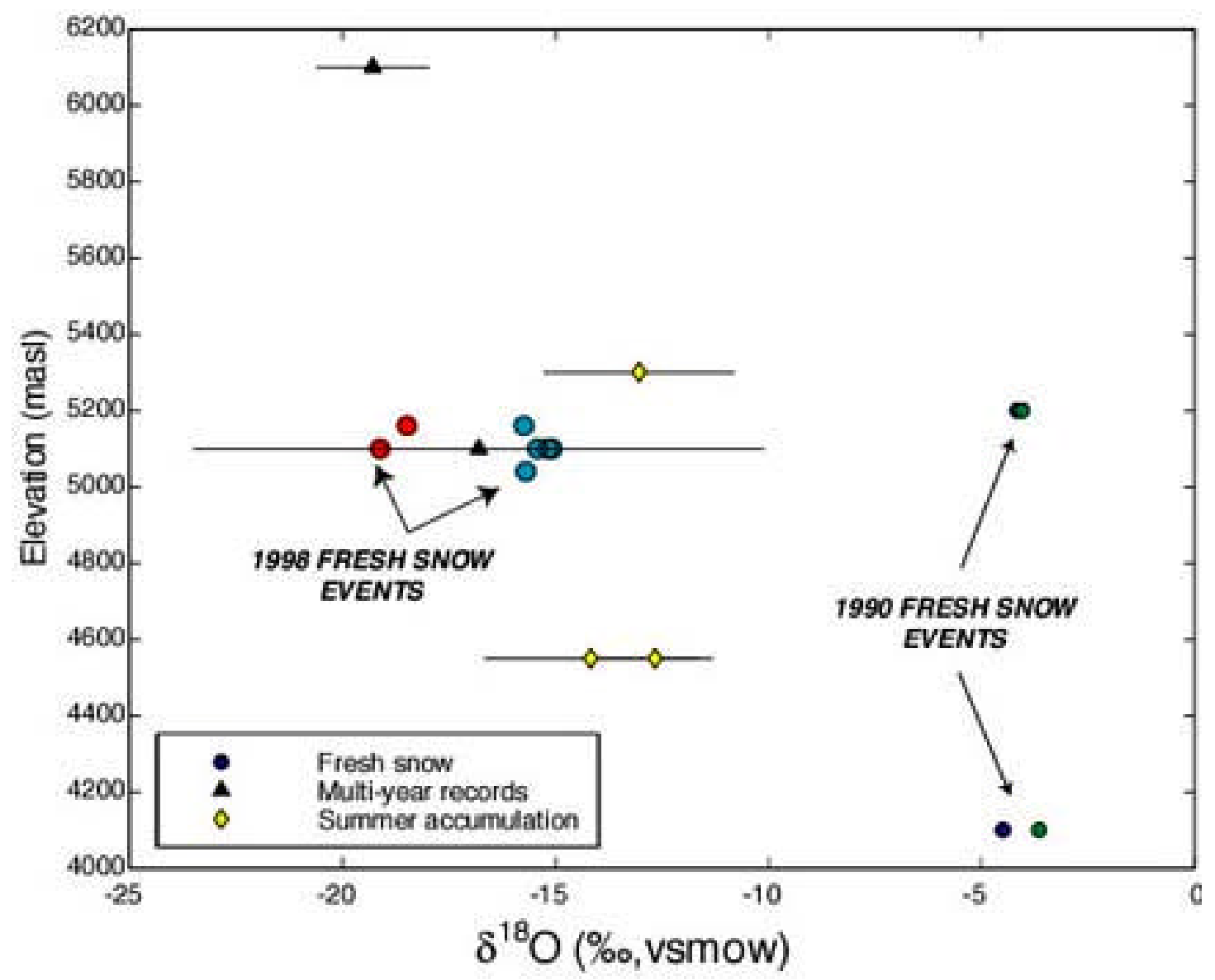

Fig. 6. Oxygen isotope ratios for a variety of snow/firn samples collected in the Inylchek Glacier Basin, central Tien Shan. Note the similarity in values collected over a range of elevations for particular events. 

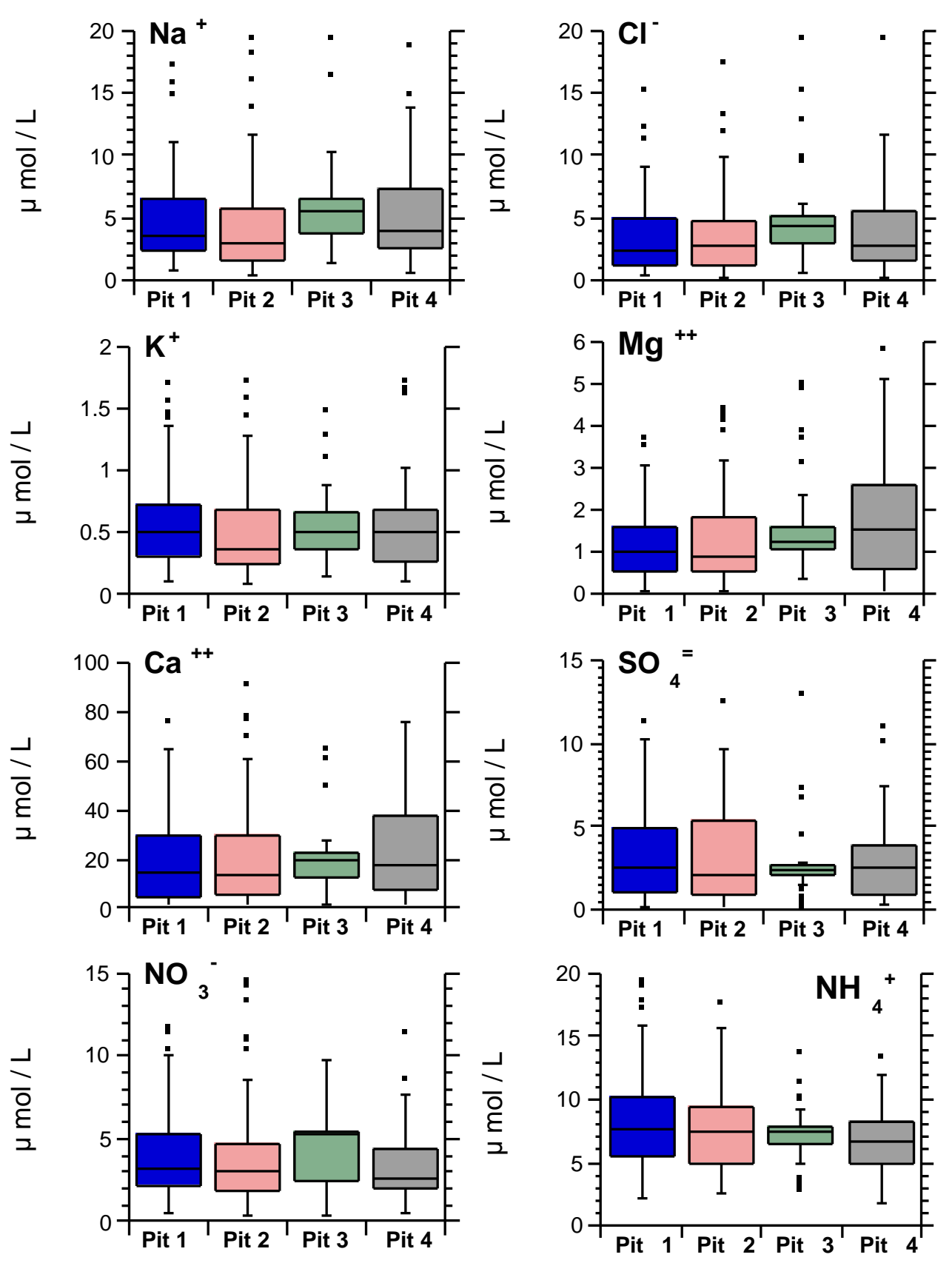

Fig. 7. Box and whisker plots showing the variability in major ion chemistry between the four snowpits. All four snowpits show similar mean values and variability, indicating that elevation is not a major control on precipitation chemistry. 


\section{Analysis of Core Chips for $\delta \mathrm{D}$}

During the drilling of both Core 1 and Core 2, ice chips produced during each core run were collected and sampled for stable isotope $(\delta D)$ analysis. Chips were collected into plastic bags, homogenized by vigorous shaking, and then sub-sampled into $20 \mathrm{ml}$ plastic vials. Two samples were collected from each core run, and 4 core runs were sampled 510 times to test the homogeneity of the chips. Samples were analyzed for $\delta D$ via gassource mass spectrometry using chrome reduction (precision $= \pm 0.5 \%$ ).

Results of core chip $\delta \mathrm{D}$ measurements are shown in Figure 8 . The isotope profiles display significant down-core variability that is consistent with signals observed in the 1998 firn core (Kreutz et al., in press). Within the errors of the sampling method (different depth intervals sampled, slight differences in site accumulation, variability due to non-homogenous sampling), the agreement of means (-112.7\%o and $-112.2 \%$ o), standard deviations (38.6\%o and $41.2 \%$ ) , and time-series variability between the two profiles is excellent. The benefit of these data is that they allow us to evaluate any potential disturbance of the down-core record from glacier dynamics. Given the excellent agreement of the isotope records from the two cores, we are confident that the climate signals preserved in the cores has not been significantly disturbed by horizontal ice-flow, and that development of high-resolution glaciochemical records from both cores will allow accurate reconstruction of climate variability.

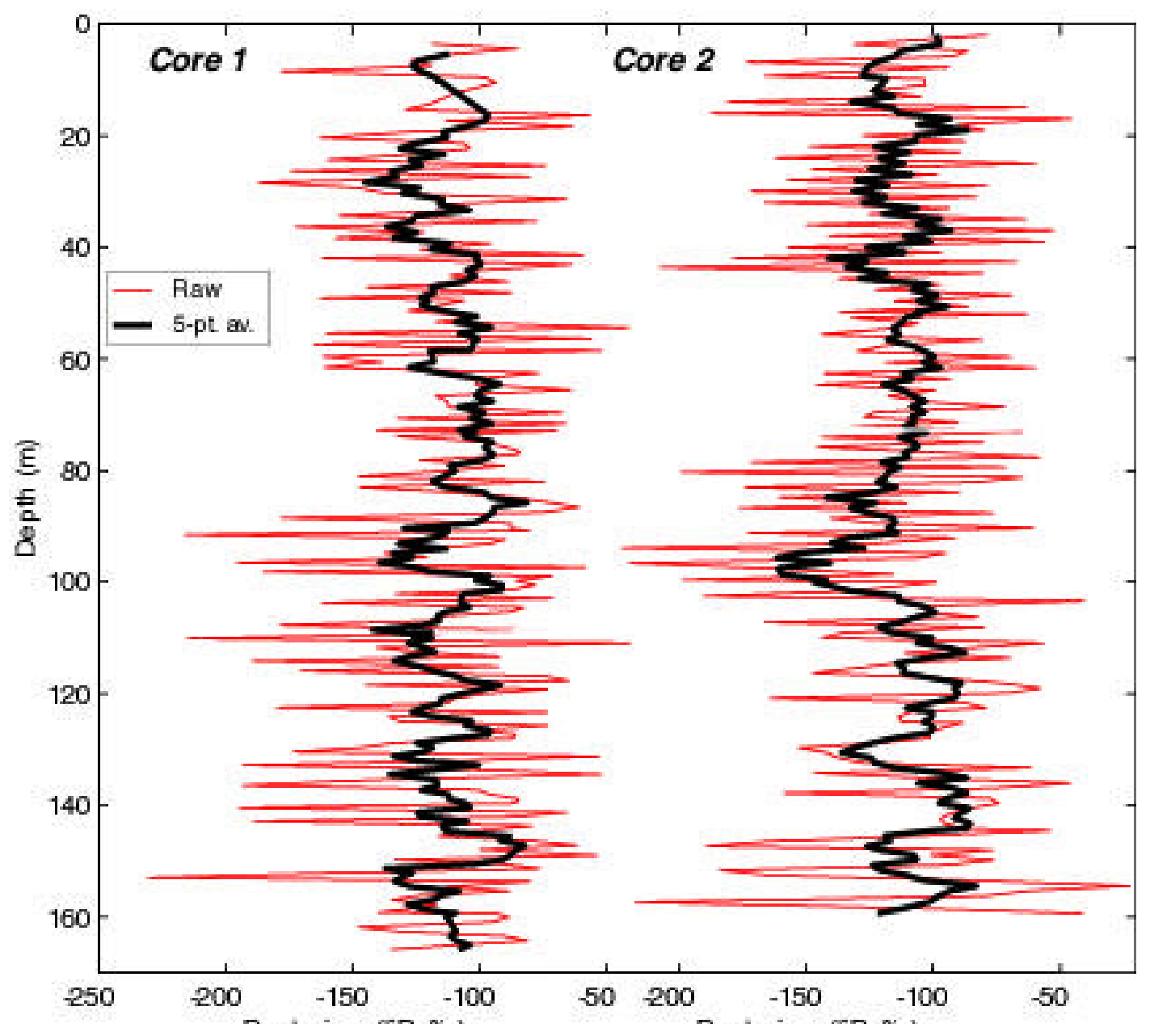

Fig. 8. Deuterium measurements on the core chips from both cores. Note the similarity in the records in both the trends and the variability. 


\section{Meteorological Measurements on the Glacier}

Field meteorological measurements were recorded near the drilling site at $5100 \mathrm{~m}$ a.s.l. using an solar powered automatic weather station made by Grant Instruments. All sensors were calibrated by Grant Instrument Laboratories before the expedition using standards of the National Physical Laboratory, United Kingdom and the World Meteorological Office. The operational range of the data logger is from -40 and $+40{ }^{\circ} \mathrm{C}$. The accuracy of air temperature/humidity probe mounted in radiation screen is $\pm 2 \% \mathrm{rh}$ ( 0 to $90 \% \mathrm{rh}$ ) and $0.2{ }^{\circ} \mathrm{C}\left(-20\right.$ to $\left.+20{ }^{\circ} \mathrm{C}\right)$. The wind speed sensor has a range $0.15-75 \mathrm{~m} / \mathrm{s}$, accuracy $\pm 1 \%$ of reading $(10 \mathrm{~m} / \mathrm{s}$ to $55 \mathrm{~m} / \mathrm{s})$ and $\pm 0.1 \mathrm{~m} / \mathrm{s}(0.1 \mathrm{~m} / \mathrm{s}$ to $10 \mathrm{~m} / \mathrm{s})$. The heated precipitation gauge has a resolution $0.1 \mathrm{~mm}$ water per tip. The solar radiation sensors waveband is 300 to $1100 \mathrm{~nm}$. The atmospheric (barometric) pressure sensor has a range between 400 and 900 mbar. Every half-hour the meteorological station recorded net total radiation balance including short- and long-wave radiation, incoming short-wave radiation, reflected from surface short-wave radiation, duration of solar radiance, atmospheric pressure, surface temperature, and precipitation. Wind direction was recorded only at the $2.0 \mathrm{~m}$ height.

This data will serve to validate altitudinal gradients of air temperature, solar radiation and the differences between glacial and non-glacial surfaces initially calculated from data at the Tien Shan meteorological station and expeditionary observations. Figure 9A and 9B show some of the meteorological variables recorded at $2.0 \mathrm{~m}$ above surface of the glacier during July-August 2000. The measurements on the glacier and at the Tien Shan meteorological station (located $150 \mathrm{~km}$ west from the drilling site at $3614 \mathrm{~m}$ ) and our preliminary meteorological measurements on the glacier at $3400 \mathrm{~m}, 4000 \mathrm{~m}, 5000 \mathrm{~m}$ and $6100 \mathrm{~m}$ in 1989, 1990,1991, 1992, 1998 and 2000 allow us to calculate air temperature gradients, and turbulent heat and humidity fluxes. Compilation of the existing long-term meteorological records from nearby meteorological stations located at different elevations in combination with our field data provides valuable information to calculate the temporal and spatial variations of the mass-energy balance components of the Tien Shan glacier system. The objective of the research is to obtain modern temporal information concerning glacier climate, to determine the main factors affecting snow/ice deposition, and to analyze the physical interactions to assist in developing paleoclimatic reconstructions from the ice core data. This data will also benefit in developing a regional atmospheric dynamics model. All collected meteorological data (field and long-term) as well as synoptic information will require significant statistical analysis and interpretation before we can apply this data to the ice-core interpretation. 


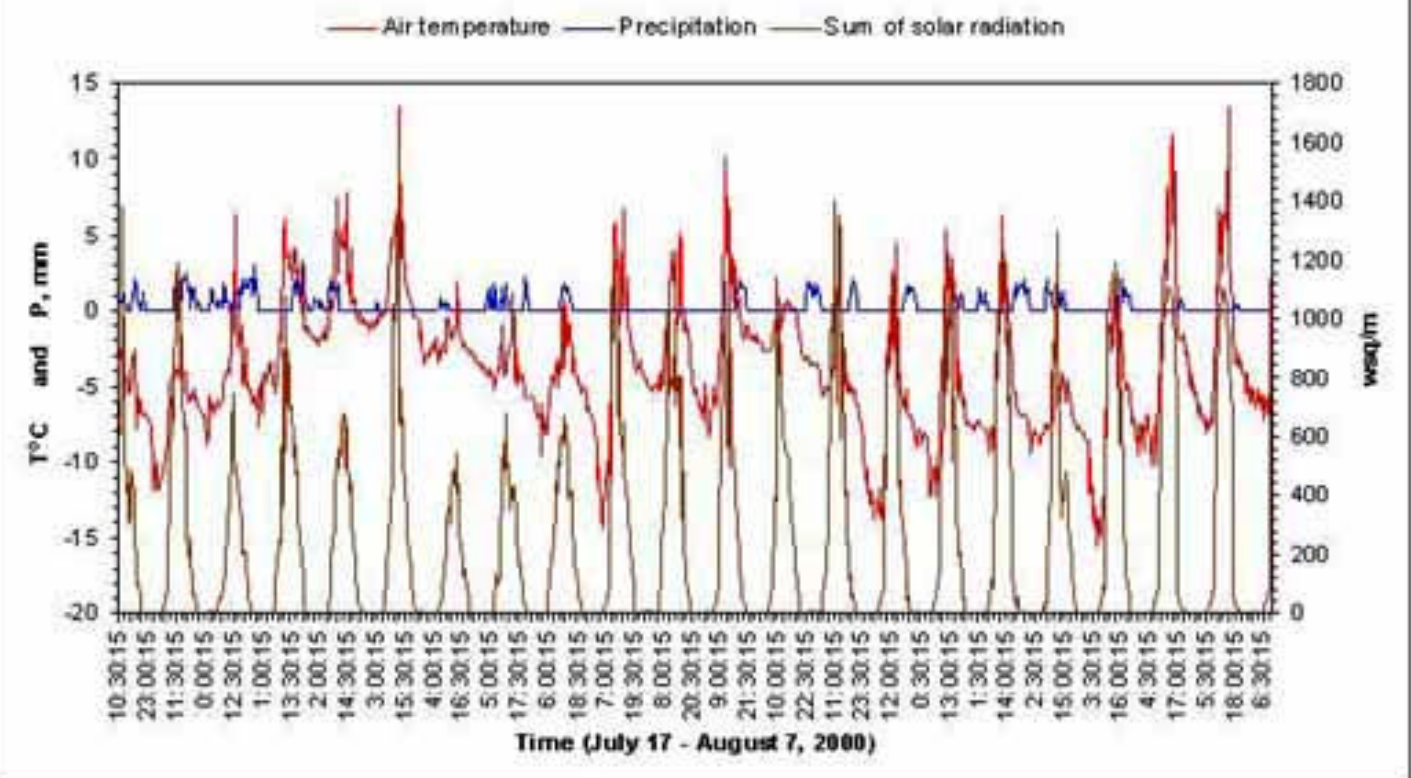

Fig. 9A. Meteorological variables measured on the Inilchek Glacier at $5100 \mathrm{~m}$ between July 17 and Aug 7, 2000.

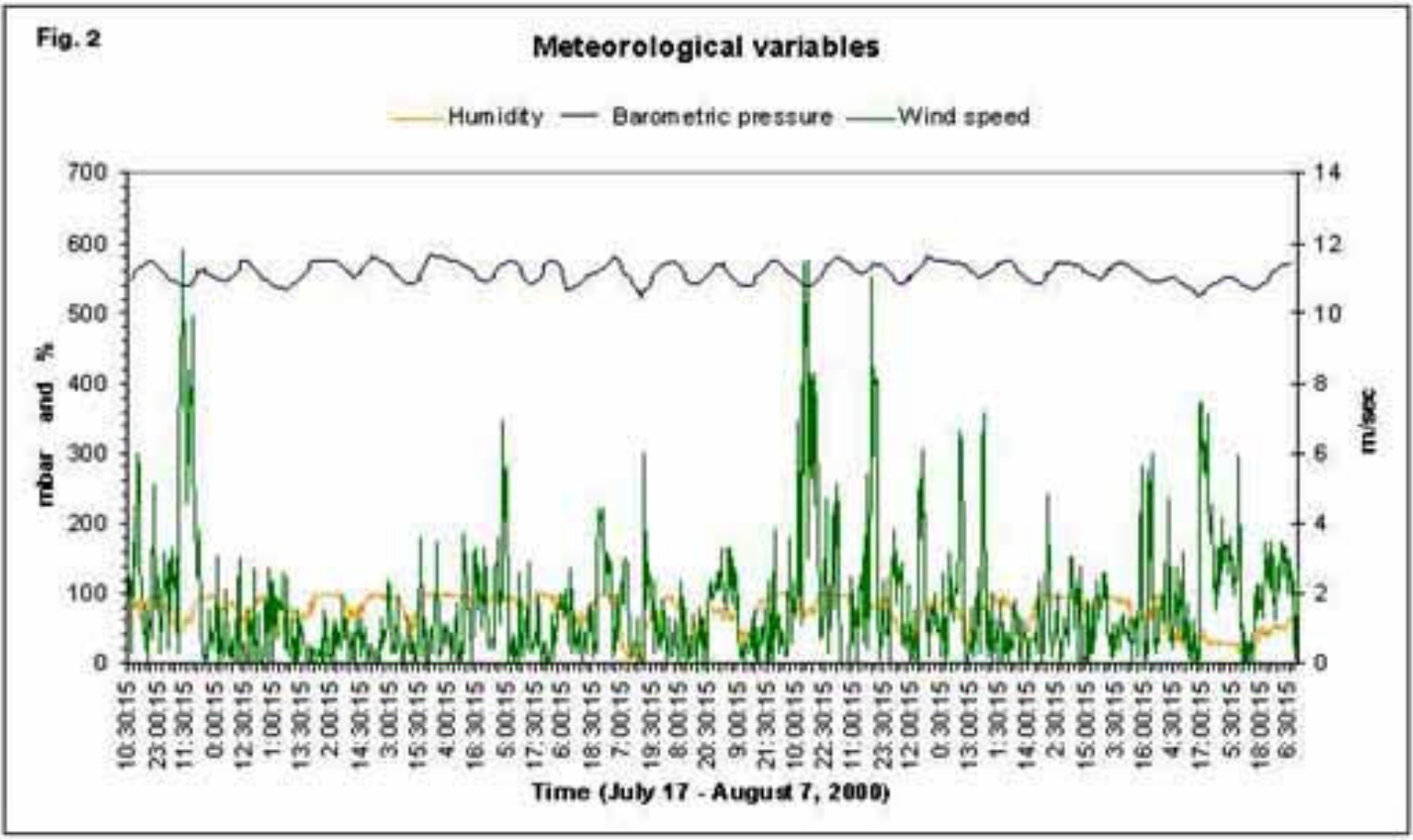

Fig. 9B. Meteorological variables measured on the Inilchek Glacier at $5100 \mathrm{~m}$ between July 17 and Aug 7, 2000. 


\section{Logging borehole number 1 for in situ gamma radiation}

A custom made portable borehole gamma spectrometer (Dunphy et al., 1994) was used to $\log$ the in-situ gamma radiation in the upper $30 \mathrm{~m}$ of borehole number 1 . We located a horizon with Cs-137 concentration well above background at $30 \mathrm{~m}$ depth. It appears as though this peak represents fallout from the 1986 Chernobyl nuclear reactor explosion and corresponds to an average accumulation rate of $1.18 \mathrm{~m}$ water equivalent per year from 1986 to the present (this accumulation estimate does not include the deposition of approximately $3 \mathrm{~m}$ of snow from an extraordinary avalanche at the beginning of the 1990 's - see details in the section below on crevasse wall stratigraphy). We are awaiting radionuclide analysis of the core chips to confirm the presence of the Chernobyl horizon at $30 \mathrm{~m}$ depth.

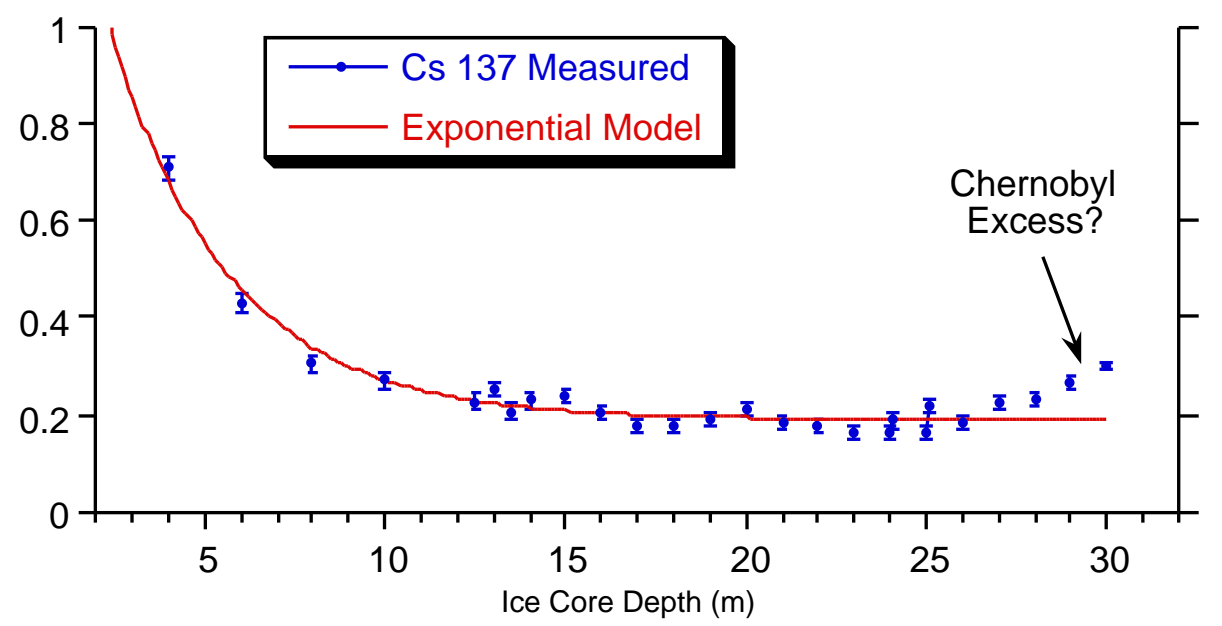

Fig 10. In situ Cs-137 measured in Borehole number 1. The data points show \pm 1 sigma error bars determined from counting statistics. The exponential model estimates the energy loss with depth due to attenuation of cosmic-ray-produced gamma-rays.

\section{Collection of core chips for radionuclide analysis}

In the upper $80 \mathrm{~m}$ of Core 1, core chips from each drill run were collected for radionuclide analysis. The procedure consisted of bagging all chips produced from each run, weighing each bag, melting the chips, filtering through glass fiber (GF/F) filters, and sealing the filters in petri dishes for transport. Surface snow and core chips from the maximum depth achieved $(167 \mathrm{~m})$ were also collected via the same procedure to assess blank levels and matrix effects. The filters were shipped to the Woods Hole Oceanographic Institution (WHOI), where they will be analyzed for the particle reactive elements of $\mathrm{Pu}, \mathrm{Np}$, and $\mathrm{Cs}$. Gamma spectrometry will be conducted using a $\mathrm{HpGe}$ planar detector for Cs analysis, and a Finnegan Element high-resolution ICP-MS will be used for $\mathrm{Pu}$ and $\mathrm{Np}$ analysis. 
To date, two filters have been analyzed (qualitatively) for Cs. The first sample, from a depth of $12.19-13.20 \mathrm{~m}$, had detectable Cs levels. The second sample, from a depth of $37.29-38.19 \mathrm{~m}$, had no detectable Cs. Quantitative Cs measurements, as well as Pu and $\mathrm{Np}$ isotopic measurements, will be made on the entire suite of filter samples to provide complete time-series records once funding is secured. The benefits of these data are twofold. First, a well-constrained depth/age relationship for ice cores from the Inilchek glacier can be constructed with a combination of radiogenic isotopes, cosmogenic isotopes, stable isotopes, major ions, and stratigraphy. Second, the combination of an accurate chronology and $\mathrm{Pu}$ and $\mathrm{Np}$ measurements will allow a more complete characterization of fallout contamination to the region.

In addition to collecting the drill chips from the upper $80 \mathrm{~m}$, scrapings from the upper $100 \mathrm{~m}$ of Core 1 that was processed in the field were collected for analyses of the radionuclides ${ }^{10} \mathrm{Be},{ }^{36} \mathrm{Cl},{ }^{129} \mathrm{I}$ and ${ }^{137} \mathrm{Cs}$. These samples were allocated to the Global Environmental Research Program in order to develop a detailed record of radionuclide deposition preserved in the ice. The major investigators studying these radioisotopes include L. DeWayne Cecil, Jaromy R. Green, and Hans-Arno Synal. The ice core samples were shipped frozen to the Paul Scherrer Institute in Zurich and are now being processed by accelerator mass spectrometry (AMS). The radionuclide records will be used to:

- Establish a time marker of fallout events from the atmospheric nuclear weapons tests in the 1950s-60s.

- Reconstruct the fallout distribution of ${ }^{36} \mathrm{Cl}$ at mid latitudes globally in conjunction with our measurements at other mid-latitude sites, most notably the Upper Fremont Glacier in Wyoming, USA (Cecil and others, 1999).

- Evaluation of ice accumulation rates at the South Inilchek Glacier.

- Establishment of the ice-core chronology in combination with stable isotopic and major trace element data.

- Reconstruction of the anthropogenic increase of ${ }^{129} \mathrm{I}$ in central Asia for comparison to this record at the Upper Fremont Glacier.

For the radionuclides ${ }^{36} \mathrm{Cl}$ and ${ }^{129} \mathrm{I}$, the first $100 \mathrm{~m}$ will be analyzed with a resolution of $1 \mathrm{~m}$ per sample using AMS. This should correspond to about sub annual time resolution and should extend back into the pre-nuclear weapons tests era. In parallel to the AMS analyses, the samples will be measured with gamma spectrometry to develop a record of ${ }^{137} \mathrm{Cs}$ fallout that peaked in 1953 and 1963.

Since a relatively large number of radionuclides are being measured, a complex chemical sample preparation protocol is being followed. We initially tested the chemical separation protocol with a set of samples before analyzing all samples. Twenty samples were prepared and measured in the first stage of the analysis for ${ }^{36} \mathrm{Cl}$ and ${ }^{129} \mathrm{I}$. Starting at a core depth of $10 \mathrm{~m}$, the samples were taken from every third meter. Preparation and analyses was completed successfully, and additional samples are now being analyzed. Preliminary results from these glacial samples show the ${ }^{36} \mathrm{Cl}$ weapons-tests peak was preserved at a depth of $92 \mathrm{~m}$ below the surface of the glacier (Figure 11), indicating a larger than expected accumulation rate at the site of the Inilchek Glacier. This larger accumulation rate will provide a record with a higher resolution than expected. In addition to ${ }^{36} \mathrm{Cl}$ and ${ }^{129} \mathrm{I},{ }^{137} \mathrm{Cs}$ measurements of the samples are in progress. 


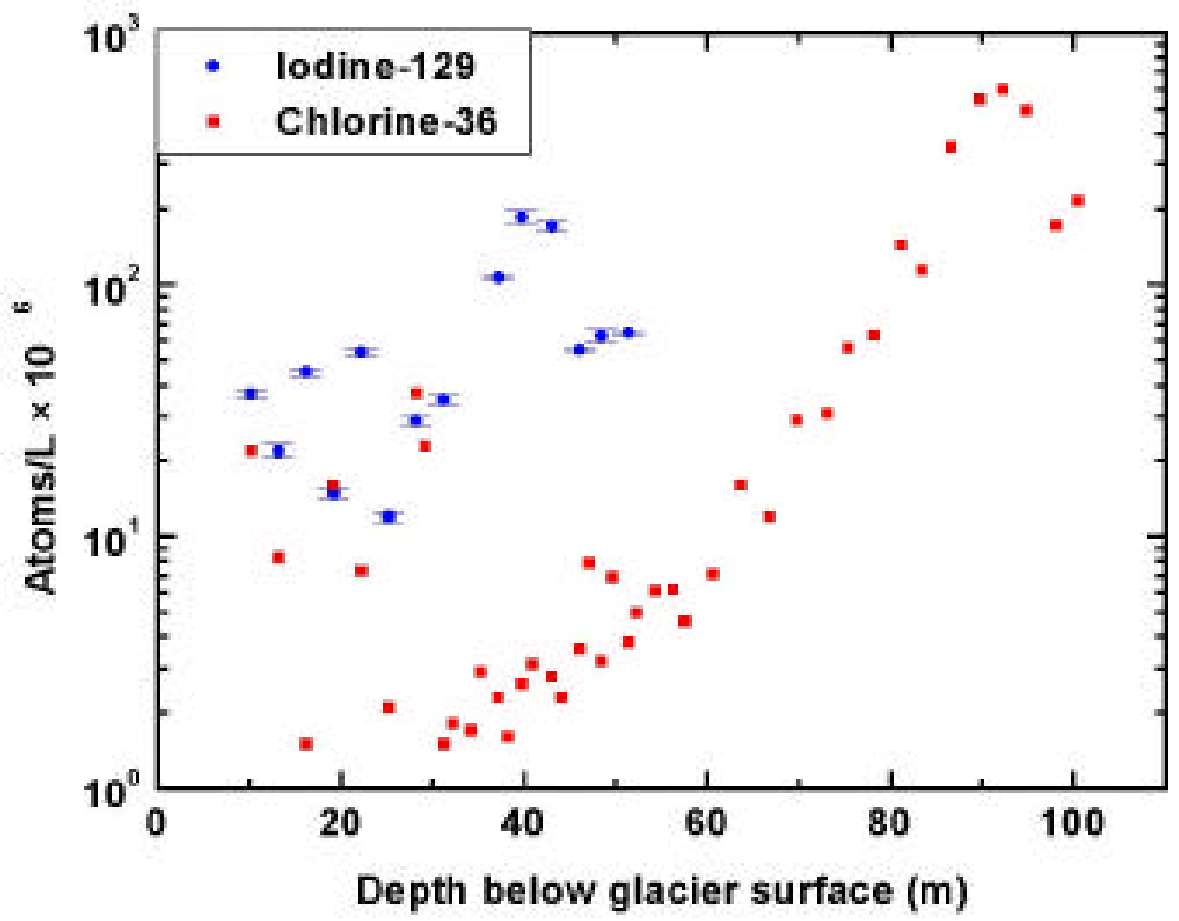

Fig. 11. Preliminary chlorine-36 and iodine-129 profiles from the ice core number 1, Inilchek Glacier, Kyrgyzstan. Weapons-tests concentrations of chlorine-36 are preserved at a depth of greater than $92 \mathrm{~m}$, indicating a larger than expected accumulation rate at this site.

\section{Collection of Snow and Ice Samples from Crevasse Wall}

We analyzed and collected snow/firn samples from a $15 \mathrm{~m}$ of a crevasse wall at $5000 \mathrm{~m}$ (Figure 4). In addition to collecting samples, the stratigraphy of the wall was described in detail (Figure 12). A north oriented wall of the ice crevasse was cleaned up to $0.5 \mathrm{~m}$ deep and $1 \mathrm{~m}$ wide along the entire $15 \mathrm{~m}$ depth. Mountaineering equipment was used to secure the scientists working in the crevasse. Snow and ice samples were collected each $10 \mathrm{~cm}$ for stable isotope and radionuclide analyses (not yet performed).

At the depth of $11.5 \mathrm{~m}$ we discovered an almost $3 \mathrm{~m}$ thick avalanche deposit that we estimate occurred during 1991 or 1992 . Dense firn/ice cobbles with diameters of 8 to 10 $\mathrm{cm}$ diameters were clearly apparent in the fine-grained firn layer. In the $199814 \mathrm{~m}$ core in the upper part of the firn plateau (Figure 4) we did not find any traces of this massive avalanche deposit. However, in Ice Core 1, and to a lesser extent in Ice Core 2, we did find evidence of this deposit. In the entire $165 \mathrm{~m}$ of the ice cores, this was the only section where we identified avalanche debris. We therefore expect that this avalanche deposit was the result of a unique event that caused the hanging glaciers on the east wall of Kan Tengri to fall to the accumulation zone of the glacier where we recovered the ice cores. We are continuing to investigate the possible cause of this event, included analysis 
of large earthquakes in central Tien Shan from Kyrgyzstan and Chinese seismological stations in the late 1980's and early 1990's.

Fg. 5

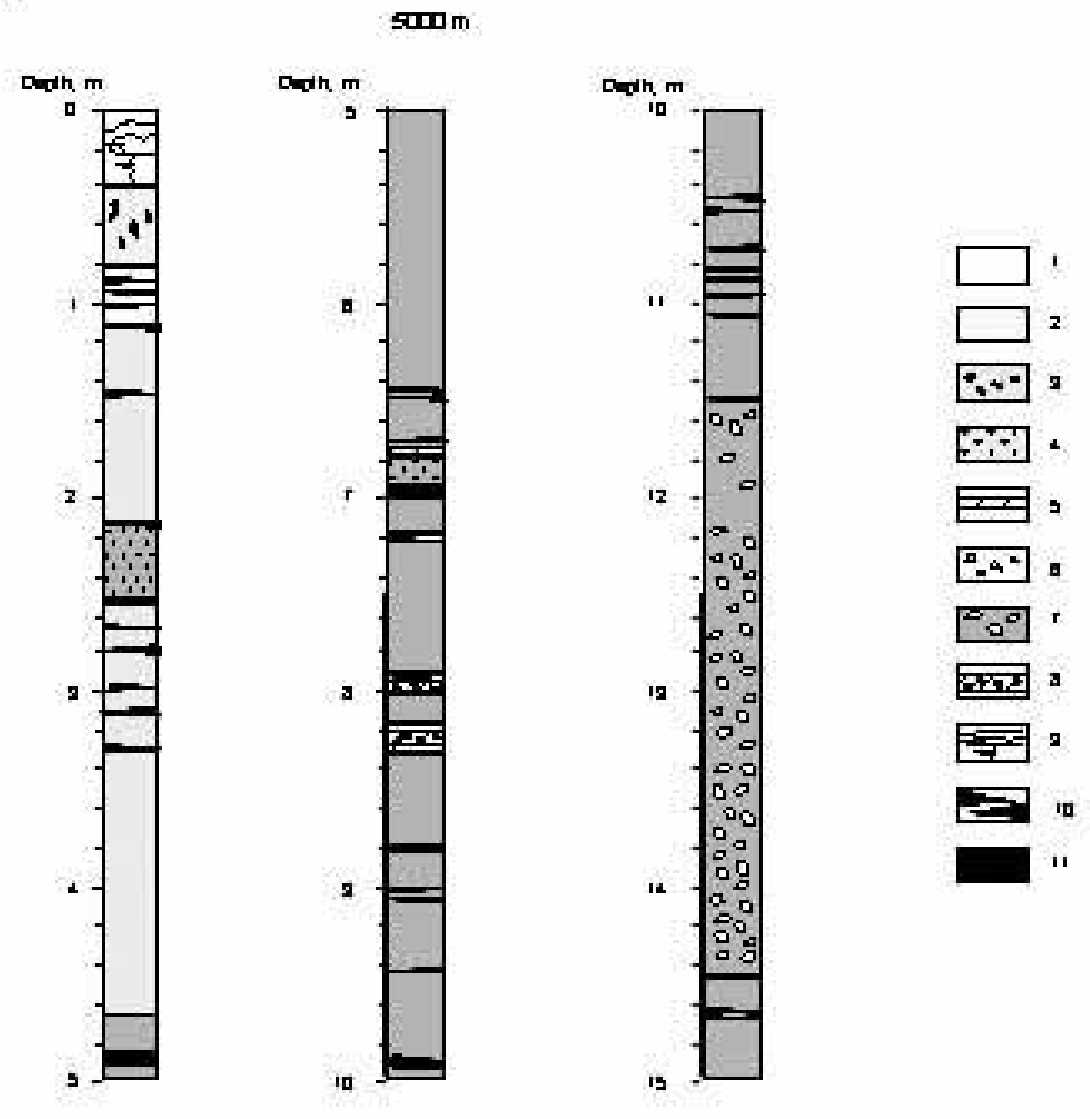

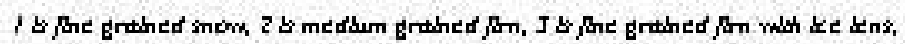

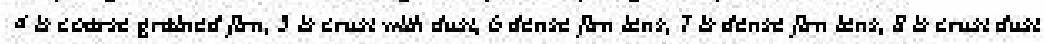

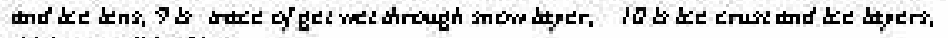

II tomenalle of tret.

Fig. 12. Physical stratigraphy of the $15 \mathrm{~m}$ crevasse wall sampled for stable isotope and radionuclide analysis. 


\section{Collection of Meteorological Data for the Tien Shan}

Table 1 provides a list of long-term meteorological data in the Tien Shan that we have collected over the past two years. This data will be use to calibrate the ice core record (on a seasonal basis) and will form a basis for our paleoclimatic reconstruction.

Table 1. Tien Shan Monthly Air Temperature and Precipitation Data.

\begin{tabular}{lllll}
\hline Station & elevation & long $(\mathrm{N})$ & lat $(\mathrm{E})$ & period of record \\
\hline Chon Ashu St. & $4050 \mathrm{~m}$ & 4227 & 7908 & $1961-1994$ \\
Tien Shan St. & $3614 \mathrm{~m}$ & 4155 & 7814 & $1930-2000$ \\
Chatir Kul St. & $3540 \mathrm{~m}$ & 4036 & 7520 & $1940-1992$ \\
Aksai St. & $3135 \mathrm{~m}$ & 4107 & 7649 & $1952-1992$ \\
Dolon St. & $3040 \mathrm{~m}$ & 4150 & 7546 & $1950-1991$ \\
Arpa St. & $3040 \mathrm{~m}$ & 4150 & 7546 & $1953-1991$ \\
Koilu St. & $2800 \mathrm{~m}$ & 4207 & 7903 & $1950-2000$ \\
Bolshaya Kyzylsu St. & $2555 \mathrm{~m}$ & 4214 & 7810 & $1948-2000$ \\
Djergalan St. & $2400 \mathrm{~m}$ & 4237 & 7902 & $1948-2000$ \\
Ikki Narin St. & $2328 \mathrm{~m}$ & 4130 & 7625 & $1932-1992$ \\
Kolcovka St. & $2150 \mathrm{~m}$ & 4204 & 7659 & $1926-1992$ \\
Narin St. & $2039 \mathrm{~m}$ & 4126 & 7600 & $1890-2000$ \\
Atbashi St. & $2025 \mathrm{~m}$ & 4110 & 7549 & $1927-1992$ \\
Saridjaz St. & $1956 \mathrm{~m}$ & 4255 & 7936 & $1959-2000$ \\
Grigorievka & $1920 \mathrm{~m}$ & 4247 & 7728 & $1930-1992$ \\
Djuuka & $1900 \mathrm{~m}$ & 4213 & 7758 & $1933-1992$ \\
Teplokluchenka & $1890 \mathrm{~m}$ & 4229 & 7831 & $1879-2000$ \\
Barskaun & $1825 \mathrm{~m}$ & 4208 & 7735 & $1932-1992$ \\
Prjevalsk & $1716 \mathrm{~m}$ & 4226 & 7826 & $1881-1994$ \\
Tamga & $1690 \mathrm{~m}$ & 4210 & 7731 & $1937-1992$ \\
Krasnii Oktyabr & $1645 \mathrm{~m}$ & 4247 & 7818 & $1933-1992$ \\
Cholpon Ata & $1645 \mathrm{~m}$ & 4210 & 7731 & $1928-2000$ \\
Ribachie & $1621 \mathrm{~m}$ & 4227 & 7611 & $1927-2000$ \\
Tup & $1620 \mathrm{~m}$ & 4244 & 7813 & $1926-1992$ \\
Kashi & $1291 \mathrm{~m}$ & 3928 & 7559 & $1951-1998$ \\
Aksu & $1104 \mathrm{~m}$ & 4113 & 8015 & $1954-1998$ \\
Tien Shan Station* & $3614 \mathrm{~m}$ & 4155 & 7814 & $1930-2000$ \\
Koilu Station* & $2800 \mathrm{~m}$ & 4207 & 7903 & $1950-2000$ \\
\hline
\end{tabular}

* daily data has been collected for these two stations 


\section{PRODUCTS}

We are currently awaiting notification concerning funding of a collaborative proposal submitted to the National Science Foundation - Paleoclimate Program that will allow us complete our analysis of the ice cores and meteorological data.

In addition to fieldwork performed during the 2000 field season, several papers dealing with samples recovered during a 1998 reconnaissance expedition and 2000 drilling expedition on the Inylchek Glacier have been completed (see list below). Copies of these papers are available online at: http://www.icess.ucsb.edu/ aizen/aizen.html. In addition, four abstracts (copied below) based on the analysis of samples collected during the 2000 field season have been submitted to the upcoming International Glaciological Society's Symposium on "Ice Cores and Climate" that will be held in Greenland in August, 2001.

\section{Tien Shan 1998 and 2000 - Papers and Abstracts}

Aizen, V.B, E.M. Aizen, K.J. Kreutz, D.L. Cecil, C.P. Wake. Association between atmospheric circulation patterns and ice core records from a snow-firn field on the Inylchek Glacier, Central Tien Shan Mountains, Asia. Journal of Geophysical Research, in review.

Aizen, E.M., V.B. Aizen, J.M. Melack, T. Nakamura, T. Ohta. Precipitation and Atmospheric Circulation Patterns at Mid-Latitudes of Asia, International Journal of Climatology, in press.

Aizen, V. B., K.J. Kreutz, C.P. Wake, D.L. Cecil, and E.M. Aizen. Meteorological Monitoring and Ice Core Reconnaissance in the Central Tien Shan. Proceedings, 1998 AGU Fall Meeting, San Francisco, A32A-03, pp. 224, 1998.

Aizen, V.B., E.M. Aizen. Estimation of glacial runoff to the Tarim River, Central Tien Shan. Proceedings of International Symposium "WaterHead'98", Merano, ITALY, IAHS Publ. No 248, 191-199, 1998.

Gerasimoff, $M$ and C.P. Wake. A Reason for Resin. J. Glaciol. in press.

Kreutz, K.J., V.B. Aizen, L.D. Cecil, and C.P. Wake. Oxygen isotopic and soluble ionic composition of precipitation recorded in a shallow firn core, Inylchek Glacier, $J$. Glaciology, in press.

Kreutz, K.J., and E.R. Sholkovitz, Major element, rare earth element, and sulfur isotopic composition of a high-elevation firn core: Sources and transport of mineral dust in Central Asia, Geochemistry, Geophysics, Geosystems $\left(G^{3}\right)$, 1, paper 2000GC000082, 2000.

Kreutz, K.J., Sholkovitz, E.R., Aizen, V.B., Aizen, E., Cecil, L.D., and Wake, C.P. The rare earth element composition of Central Asian dust: A new ice-core proxy for atmospheric aerosol loading, source, and transport pathways. Proceedings AGU Fall Meeting, San Fransisco, 1999. 


\section{REFERENCES:}

Aizen, V.B., E.M. Aizen, J.M. Melack, and J. Dozier. Climate and hydrologic changes in the Tien Shan, central Asia. J. Climate, 10, 218-229, 1997.

Aizen, V.B., E.M. Aizen, J.M. Melack, and T. Martmaa. Isotopic measurements of precipitation on central Asian glaciers. (Southeastern Tibet, northern Himalayas, central Tien Shan). J.Geophys. Res., 101, 9185-9196, 1996.

Blake, E, Wake, C. and Gerasimoff, M. The ECLIPSE drill: a field portable intermediatedepth ice-coring drill. Journal of Glaciology, 44, 175-178, 1998.

Dunphy, P. P. and J. E. Dibb. Cs-137 gamma-rays from fallout detected at Summit, Greenland. J. Glaciol., 40, 87-92. 1994.

Kreutz, K.J., V.B. Aizen, L.D. Cecil, and C.P. Wake. Oxygen isotopic and soluble ionic composition of precipitation recorded in a shallow firn core, Inylchek Glacier, $J$. Glaciology, in press.

Kreutz, K.J., and E.R. Sholkovitz, Major element, rare earth element, and sulfur isotopic composition of a high-elevation firn core: Sources and transport of mineral dust in Central Asia, Geochemistry, Geophysics, Geosystems $\left(G^{3}\right)$, 1, paper 2000GC000082, 2000.

Mayewski, P.A., W.B. Lyons, N.Ahmad, G. Smith, and M. Pourchet. Interpretation of the chemical and physical time-series retrieved from Sentik Glacier, Ladakh Himalaya, India. J. Glaciol. 30, 66-76, 1984.

Thompson, L.G., T. Yao, E. Mosley-Thompson, M. E. Davis, K. A. Henderson, and P.N. Lin. A High-Resolution Millennial Record of the South Asian Monsoon from Himalayan Ice Cores. Science 289, 1916-1919, 2000.

Thompson, L.G. and eight others, Tropical Climate Instability: The last glacial cycle froma Qinghai-Tibetan ice core. Science 276, 1821-1825. 1997.

Thompson, L.G., E. Mosley-Thompson, M.E.Davis, P.N.Lin, J.Dai and J. Bolzan. A 1000 year ice core climate record from the Guliya Ice Cap, China: its relationship to global climate variability. Annals of Glaciology, 21, 175-181. 1995.

Thompson, L.G., E. Mosley-Thompson, M.E.Davis, J. Bolzan, J.Dai, T.Yao, N.Gundestrup, X.Wu, L.Klein, and Z.Xie. Holocene-Late Pleistocene climatic ice core records from Qinghai-Tibetan Plateau. Science, 246, 474-477. 1989.

Wagenbach, D. The enviromnet records in alpine glaciers. H. Oeschger et al. (eds), The Environmental Record in Glaciers and Ice Sheets. Dahlem Workshop Reports Physical, Chemical, and Earth Science Research Report, 8, 69-83, 1989.

Wake, C.P., Ice Core Records of Climate Change in the Himalaya/Tibetan Plateau region during the last 200 years. Proceeings AGU Fall meeting, San Fransisco, 1998

Wake, C.P. and Mayewski, P. (editors). Himalayan Interdisciplinary Paleoclimate Project - Science and Implementation Plan. IGBP-PAGES Workshop Report 96-1, 1996. 
Abstracts resulting from our Tien Shan research that have been accepted for presentation at the International Glaciological Symposium on "Ice Cores and Climate", Greenland, August 2001.

\title{
An approach for interpretation of ice-core paleo-climatic records from the central Tien Shan based on complex of isotopes/major ions composition and long-term meteorological/synoptic data
}

\author{
Vladimir B. Aizen, Elena M. Aizen, Cameron P. Wake, Karl J. Kreutz, and L. DeWayne \\ Cecil
}

Deep ice-cores obtained from mid-latitude alpine glaciers provide records of climate and environmental change extending back hundreds to thousands of years at the latitude, which are home to the majority of the Earth's human population. Paleoclimatic records developed through the chemical and physical analysis of ice cores can be used to document regional changes in atmospheric circulation and climate, water resources, and environmental impact. However, developing calibrated paleorecords requires a broad array of long-term surface data that can be used to compare with THE ice core records. Only a few alpine regions have suitable firn/ice fields at elevations over $5000 \mathrm{~m}$ for which there exists long-term meteorological data sufficient to be representative of climatological parameters. The Tien Shan Mountains is one of them. In summer 2000 two $160 \mathrm{~m}$ firn/ice cores have been recovered from an elevation of 5100 and $5120 \mathrm{~m}$ in the accumulation zone of the Inilchek Glacier, Central Tien Shan. Both of these cores were transported frozen to U.S.A. where they are currently stored for processing. Here we report on analysis of a $15 \mathrm{~m}$ core recovered in 1998 .

The method of evaluation and interpretation of the Tien Shan ice cores is based on multiple source analyses. Using standard simple and multiple regression, and factor analysis, the ice core data IS compared with meteorological data on a seasonal and annual variability (e.g., temperature, precipitation) and indices of atmospheric circulation patterns (frequency of the main synoptic processes; ZACP, $\mathrm{M}_{1,2} \mathrm{ACP}$, NOA, WPO, PNA etc.). The soluble ionic content of precipitation reflects different moisture sources and areas over moisture was transported. Hence, precipitation chemistry is closely linked to synoptic processed and compared with the frequency of fourteen synoptic processes using correlation analysis. Simultaneously, we analyzed the information on dust storms (e.g., their origination, trace and frequency and intensity). According to our first results, the soluble major ion content of snow deposited in the Tien Shan clearly reflects changes in the prevailing atmospheric patterns in the Central Tien Shan. The meteorological and synoptic time series analysis allows development of the multi-regression model for paleoclimatic reconstruction. These results provide valuable input for the simulation of glacier mass balance. For example, the cycles of atmospheric circulation patterns with year peak energies may be taken into account in long-term probabilistic model of glacier mass balance evaluation. 


\title{
Chlorine-36 and Iodine-129 in Ice Cores Collected from Inilchek, Nangpai Gosum, and Upper Fremont Glaciers
}

\author{
L. DeWayne Cecil, Hans-Arno Synal, Jaromy R. Green, Javiers Santos, Jüreg Beer,
} David L. Naftz, Karl J. Kreutz, Cameron P. Wake, and Vladimir B. Aizen

The U.S. Geological Survey (USGS) is conducting a collaborative isotopic research program on mid-latitude glaciers around the world. Three of the glaciers being studied are the Inilchek Glacier, located in the Tien Shan Mountains on the borders of Kyrgyzstan, Kazakhstan, and China, the Nangpai Gosum Glacier located in the Himalayan Mountains of Nepal, and the Upper Fremont Glacier located in the Wind River Mountain Range of Wyoming, U.S.A.

Measurements for radioactive chlorine-36 $\left({ }^{36} \mathrm{Cl}\right)$ and iodine-129 $\left({ }^{129} \mathrm{I}\right)$ have been conducted on ice cores collected from these three glaciers. These analyses were performed by accelerator mass spectrometry at Purdue University's PRIME Laboratory, U.S.A. and the Paul Scherrer Institute, Switzerland. The ${ }^{36} \mathrm{Cl}$ profiles from the ice cores reflect ambient concentrations, the rise and fall of nuclear-weapons tests input, and modern anthropogenic input from nuclear facilities and nuclear accidents around the world. Although the ${ }^{36} \mathrm{Cl}$ concentrations vary considerably between the two glacial sites being studied due to local or regional effects, the shapes of the profiles are similar.

A preliminary ${ }^{129}$ I profile from the Inilchek Glacier ice core shows the rise and fall of anthropogenic ${ }^{129}$ I produced during the nuclear-weapons testing era. An ${ }^{129}$ I profile of the Upper Fremont Glacier ice core is expected to show large ${ }^{129}$ I releases from the U.S. Department of Energy's Hanford Site, U.S.A. This information is being used to refine the ice-core chronology and to perform dose reconstruction to human population due to these atmospheric releases.

TOPIC ADDRESSED: (3) Comparison of results from different ice cores

\section{Spatial and seasonal variability of major ion snow chemistry in the Central Tien Shan}

\author{
Karl J. Kreutz, Cameron P. Wake, Vladimir B. Aizen, and L. DeWayne Cecil
}

During summer 2000, two deep (165 m) ice cores were recovered from the Inilchek Glacier (Central Tien Shan Mountains, Kyrgyzstan) at elevations of 5100 and 5120m. High-resolution (annual to interannual) records of climate and environmental variability covering the last several hundred years are being developed from these cores. To improve the understanding of modern atmospheric processes and hence the interpretation of past climate variability in the Tien Shan, we examine here stable isotope $\left(\delta^{18} \mathrm{O}\right.$ and $\left.\delta \mathrm{D}\right)$ data from precipitation (rain and fresh snow) and snowpit samples collected during several field expeditions $(1989,1990,1992,1998,1999$, and 2000) in the Tien Shan. Overall, sampling sites range in elevation from $1620 \mathrm{~m}$ to $5250 \mathrm{~m}$, and span a distance of over $60 \mathrm{~km}$, allowing regional-scale processes to be investigated. Surrounding the drillsite, several (8) snowpits and 10 fresh snow events have been sampled, and thus local-scale variability can also be addressed. Mean $\delta^{18} \mathrm{O}$ values from multi-year snowpits in the drillsite basin display little spatial or elevational variability, suggesting that precipitation processes are not strongly affected by adiabatic temperature changes within limited $(150 \mathrm{~m})$ elevation gradients. Moreover, significant wind redistribution of snowfall is likely not a factor. Fresh snow samples collected from individual events within the basin display little $(<1 \%$ ) spatial and elevational variability. Fresh snow 
samples collected from individual events both in the drillsite basin $(5100-5250 \mathrm{~m})$ and lower in the valley $(4100 \mathrm{~m})$ also have $\delta^{18} \mathrm{O}$ values that are identical (within the sampling error). It therefore appears that processes at the precipitation cloud base layer may be controlling snow $\delta^{18} \mathrm{O}$. Local meteoric water line relationships $\left(\delta^{18} \mathrm{O}\right.$ vs. $\left.\delta \mathrm{D}\right)$, isotope/meteorological correlations, and fractionation models to explain the lack of observed elevational variability will be discussed.

TOPIC ADDRESSED: (3) Meteorological, modeling and air-snow transfer studies aimed at improving ice-core interpretation

\title{
Spatial and seasonal variability of major ion snow chemistry in the Central Tien Shan
}

\author{
Cameron P. Wake, Karl J. Kreutz, Vladimir B. Aizen, and L. DeWayne Cecil
}

As part of an ice core drilling program in the central Tien Shan during the summer of 2000, we collected over 600 samples from seven separate fresh snowfall events and from four snowpits over a range of elevations (5000 to $5300 \mathrm{~m}$ ) to investigate the spatial and temporal variability of major ion snow chemistry in the accumulation zone of the Inylchek glacier.

The major ion concentrations in the fresh snow samples show much larger variability between events compared to changes in concentration with elevation, indicating a minimal influence of elevation on the major ion content of precipitation over the range of elevations sampled. The changes in precipitation chemistry between events will be compared with synoptic weather patterns to determine the source of major ions in summertime snowfall in the central Tien Shan. Mean major ion concentrations from the four snowpits show no statistical differences. The major ion profiles from the $4 \mathrm{~m}$ snowpits display considerable seasonal variability that is similar in all four pits. These results indicate that the major ion content of precipitation falling in the accumulation zone of the Inylchek Glacier is not significantly affected by the surface elevation between 5000 and $5300 \mathrm{~m}$, but rather by the source regions for the precipitation and the major ions, and/or changes in atmospheric circulation. The variability in the long-term ice core glaciochemical time-series should therefore provide a record related to changes in the climate system.

TOPIC ADDRESSED: (3) Meteorological, modeling, and air-snow transfer studies aimed at improving ice-core interpretation 